\title{
Inorganic carbon availability and the growth of large marine diatoms
}

\author{
Joel C. Goldman* \\ Department of Ocean Sciences, University of California, Santa Cruz, California 95060, USA
}

\begin{abstract}
To address the question of whether free $\mathrm{CO}_{2}$ can be a growth-limiting nutrient in oceanic waters 3 large marine diatoms, Stephanopyxis palmeriana (Greville) Grunow, Ditylum brightwellii (T. West) Grunow in Van Heurck 1883, and Coscinodiscus sp., were grown in pH-drift experiments under batch culture conditions. The cultures were maintained under quiescent conditions without added buffer in the growth medium, allowing the $\mathrm{pH}$ to rise and the free $\mathrm{CO}_{2}$ concentration to fall as growth proceeded. Growth rates were constant for sustained periods and only decreased as the pH rose to as high as 8.5-8.6 and the free $\mathrm{CO}_{2}$ concentration fell to $\sim 4 \mathrm{~mol} \mathrm{l}^{-1}$ Such a low free $\mathrm{CO}_{2}$ concentration is far below the expected half saturation coefficient for ribulose biphosphate carboxylase-oxygenase (RUBISCO) and suggests that these species were capable of utilizing $\mathrm{HCO}_{3}{ }^{-}$in some fashion so as not to allow free $\mathrm{CO}_{2}$ to become growth-limiting. Additional experiments were conducted with these and other diatoms to demonstrate that turbulent mixing at high $\mathrm{pH}$ levels had no effect on inorganic carbon uptake or growth rate and that $\mathrm{HCO}_{3}{ }^{-}$uptake probably was occurring. Turbulent mixing should have enhanced inorganic carbon uptake by lowering diffusion gradients had these species been obligate users of free $\mathrm{CO}_{2}$. These species, being the most susceptible to diffusion-controlled uptake of free $\mathrm{CO}_{2}$ because of their long diffusion paths, represent the worst case scenario for free $\mathrm{CO}_{2}$ limitation. Finally, by developing a chemical-biological model it was possible to show that, in order for the $\mathrm{pH}$ of marine waters to rise even several tenths above ambient levels, biomass concentrations must increase to levels that are never found, except possibly on occasion in estuarine or coastal waters. Thus it seems unlikely that free $\mathrm{CO}_{2}$ limits phytoplankton growth in the oceans.
\end{abstract}

KEY WORDS: Inorganic carbon availability $\mathrm{pH}$ levels $\cdot \mathrm{HCO}_{3}^{-}$uptake $\cdot$ Growth $\cdot$ Large marine diatoms

\section{INTRODUCTION}

Large marine diatoms, because they are able to respond effectively to episodic physical events, may be major contributors to new production in the open ocean (Goldman 1988, 1993). Moreover, they are the first trophic level in food chains that support the production of large fish (Ryther 1969, Michaels \& Silver 1988, Moloney et al. 1991). Yet, we still do not fully understand how these organisms subsist in the open ocean and why and how they bloom on occasion. Although their nutritional requirements are typical of phytoplankton growing exponentially and their chemical composition is frequently found to be in Redfield proportions (Goldman

\footnotetext{
·E-mail: jgoldman@cats.ucsc.edu
}

et al. 1992), there still is uncertainty as to which of the commonly studied nutrients control their growth. Compared to the more sparingly available nutrients that might limit growth (nitrogen, phosphorus, silica, and, more recently observed, iron), total dissolved inorganic carbon $\left(\mathrm{C}_{1}=\mathrm{CO}_{2}+\mathrm{HCO}_{3}^{-}+\mathrm{CO}_{3}{ }^{2-}\right)$ is present in the open ocean in great excess $\left(\sim 2 \mathrm{mmol} \mathrm{I}^{-1}\right)$ relative to phytoplankton needs. Hence, $C_{1}$ historically has not been considered to be a limiting nutrient for growth even though carbon constitutes the largest fraction of phytoplankton biomass. The assumption underlying this conclusion is that all of $\mathrm{C}_{\mathrm{t}}$ is a substrate for growth, either by the adequate supply of free $\mathrm{CO}_{2}$ from the chemical equilibrium system $\mathrm{CO}_{2} \rightleftharpoons \mathrm{HCO}_{3}{ }^{-} \longrightarrow \mathrm{CO}_{3}{ }^{2-}$ or by direct uptake of $\mathrm{HCO}_{3}^{-}$, or by both mechanisms. At the prevailing $\mathrm{pH}$ of seawater $(-8.1$ to 8.2$) \mathrm{HCO}_{3}{ }^{-}$is the dominant chemical species $\left(-85 \%\right.$ of $\left.\mathrm{C}_{t}\right)$ and free $\mathrm{CO}_{2}$ 
is present at a concentration of only 10 to $15 \mu \mathrm{mol} \mathrm{l}^{-1}$. Even lower free $\mathrm{CO}_{2}$ concentrations can occur at the cell surface when diffusion controls nutrient uptake (Gavis \& Ferguson 1975, Wolf-Gladrow \& Riebesell 1997). Thus if marine phytoplankton species were obligate users of free $\mathrm{CO}_{2}$, it is conceivable that free $\mathrm{CO}_{2}$ concentrations could fall to growth-rate-limiting levels (Gavis \& Ferguson 1975, Riebesell et al. 1993). The recent claim that free $\mathrm{CO}_{2}$ plays a major role in controlling marine primary productivity is based on this premise (Riebesell et al. 1993, Hein \& Sand-Jensen 1997). If true, we would expect the effect to be greatest in large phytoplankton species that possess correspondingly thick diffusion boundary layers and hence long diffusion paths. As clearly shown by Koch (1971), the specific uptake rate of a solute controlled solely by diffusion is proportional to the reciprocal of the square of the cell diameter (see also Goldman 1984, Chisholm 1992, Kiorboe 1993). Hence. diffusion limitation becomes increasingly important as cell size increases.

A small rise in $\mathrm{pH}$ levels in natural waters resulting from phytoplankton growth can lead to a drastic reduction in the free $\mathrm{CO}_{2}$ concentration. For example, when the $\mathrm{pH}$ of seawater rises to 8.3 the free $\mathrm{CO}_{2}$ concentration drops to $\sim 7 \mathrm{\mu mol}^{-1}$; at $\mathrm{pH} 8.5$ it is down to $\sim 4 \mu \mathrm{mol} \mathrm{I}^{-1}$. Thus if marine phytoplankton were obligate users of $\mathrm{CO}_{2}$ we would expect to see large reductions in phytoplankton growth rates with even small increases in pH above ambient levels. Because of a great demand for inorganic carbon, large increases in culture $\mathrm{pH}$, often to above 9 , frequently occur in laboratory enrichment cultures (Goldman et al. 1982). As such, we would expect $\mathrm{CO}_{2}$ limitation, if it exists at all, to be most prevalent in such an environment. In contrast, nutrients levels in the ocean generally are too low to support sufficient phytoplankton growth to cause even modest increases in $\mathrm{pH}$, except in highly productive coastal and estuarine waters. Although oceanic $\mathrm{pH}$ data are scant, the $\mathrm{pH}$ of surface waters rarely exceeds $\sim 8.2-8.3$ (Clayton et al. 1995, Millero 1996). Thus through a simple ' $\mathrm{pH}$-drift' experiment it should be possible to determine whether or not growth rates of marine phytoplankton are limited by free $\mathrm{CO}_{2}$. Such an experiment would involve growing phytoplankton in enriched seawater without added buffers and under quiescent conditions. Then, by observing if changes in growth rate occur as the $\mathrm{pH}$ rises and the free $\mathrm{CO}_{2}$ concentration falls, it should be possible to address definitively the question of obligate $\mathrm{CO}_{2}$ use. Experiments of this type were performed in the current study with large marine diatoms since this phytoplankton group is most susceptible to diffusion control of $\mathrm{CO}_{2}$ transport to the cell surface; hence, they would be among the first phototrophs to experience $\mathrm{CO}_{2}$ limitation. Additionally, comparisons were made of cultures grown with and without mixing to determine the possible role of induced turbulence in enhancing growth rates by breaking down diffusion gradients of $\mathrm{CO}_{2}$. And, finally, a simple chemical-biological model was developed to determine the growth conditions that would be required to raise seawater $\mathrm{pH}$ to levels commensurate with $\mathrm{CO}_{2}$ limitation in obligate users of free $\mathrm{CO}_{2}$. The results have bearing on the recent claim that free $\mathrm{CO}_{2}$ limits growth of phytoplankton in seawater and on the resulting implications as to how global change might impact on marine primary productivity.

\section{METHODS}

Test species and enrichment medium. Four large diatoms, Coscinodiscus sp., Ditylum brightwellii (T. West) Grunow in Van Heurck (1883), Odontella mobiliensis (Bailey) Grunow, and Thalassiosira weissfloggii (Grun) Fryxell et Hasle, were obtained from the Provasoli-Guillard National Center for Culture of Marine Phytoplankton (CCMP), while a fifth large diatom, Stephanopyxis palmeriana (Greville) Grunow, was collected by net tow from the Sargasso Sea during May 1989 and maintained in culture. The diatoms ranged in size from $T$. weissfloggii $(12 \times 20 \mu \mathrm{m})$ to S. palmeriana $(100-120 \times 50 \mu \mathrm{m})$ (see Table 1). The enrichment medium for all experiments was MET 44 (Schöne \& Schöne 1982), consisting of $40 \mu \mathrm{M} \mathrm{NaNO}, 2.58 \mu \mathrm{M} \mathrm{NaHPO}, 35.7 \mu \mathrm{M} \mathrm{Na}_{2} \mathrm{SiO}_{3}$ $2.16 \mu \mathrm{M} \mathrm{Na}{ }_{2}$ EDTA, $0.215 \mu \mathrm{M} \mathrm{FeSO}, 0.073 \mu \mathrm{M} \mathrm{MnCl}_{2}$, and $0.5 \mu \mathrm{g} \mathrm{l}^{-1}$ each of vitamin $\mathrm{B}_{\mathrm{t} 2}$, biotin, and thiamine added to Sargasso seawater that had been filtered through glass fiber filters (Whatman GF/F). After the chemical additions, the seawater medium was pasteurized at $90^{\circ} \mathrm{C}$ for $2 \mathrm{~h}$ in polycarbonate bottles. After cooling the $\mathrm{pH}$ of the medium was $\sim 8.1$ (see below).

pH-drift experiments. Batch growth experiments were conducted in large Fernbach flasks containing 1.5 l of medium with 3 species, Stephanopyxis palmeriana, Ditylum brighwellii, and Coscinodiscus sp. The inoculum for each culture came from exponentially growing cells of stock cultures maintained on MET 44. Care was taken to ensure that starting cell concentrations were low enough $\left(\sim 1\right.$ to 2 cells $\mathrm{ml}^{-1}$ for $S$. palmeriana and Coscinodiscus sp. and $<100$ cells $\mathrm{ml}^{-1}$ for $D$. brightwellii) so as not to alter measurably the initial $\mathrm{pH}$ of the medium. Cultures were maintained in an environmental incubator $\left(20^{\circ} \mathrm{C}\right.$ and $-190 \mu \mathrm{Ein} \mathrm{m}^{-2} \mathrm{~s}^{-1}$ continuous irradiance) and were vigorously mixed for $-10 \mathrm{~s}$ before sampling. Time-course sampling for cell counts, $\mathrm{C}_{1}$, and $\mathrm{pH}$ commenced once visible growth was observed, usually within 2 to $3 \mathrm{~d}$ of inoculation. Samples were collected once daily in the early stages of each experiment, but more frequently when changes in $\mathrm{pH}$ occurred. Specific growth rates $\left(\mu\right.$ in $\left.\mathrm{d}^{-1}\right)$ 
were calculated by regression analysis as the slope of the linear portion of the curve of $\ln ($ cell number) versus time.

Turbulence experiments. To test the effect of induced turbulence on $C_{1}$ uptake all 5 species first were grown under conditions identical to those in the $\mathrm{pH}$-drift experiments. After 3 to $5 \mathrm{~d}$ of growth (depending on species) and after a noticeable rise in $\mathrm{pH}$ was observed, $1 \mathrm{~h}$ single-end-point or $24 \mathrm{~h}$ time-series $\mathrm{H}^{14} \mathrm{CO}_{3}{ }^{-}$labeling experiments were performed on mixed and unmixed samples. First, a small sample was taken for measurement of $\mathrm{pH}$ and $\mathrm{C}_{\mathrm{t}}$ a after this a larger sample was taken, enriched with MET 44 nutrients, trace metals, and vitamins in the same concentrations used to grow the cultures, and then split into 2 equal portions. Approximately $1 \mu \mathrm{Ci} \mu \mathrm{mol} \mathrm{C} \mathrm{C}^{-1} \mathrm{H}^{14} \mathrm{CO}_{3}^{-}$was added to 1 portion and samples taken immediately for measurement of the specific activity of the $\mathrm{C}_{1}$. Replicate $20 \mathrm{ml}$ screw-capped vials were then filled, 1 with labeled culture for measurement of $\mathrm{H}^{14} \mathrm{CO}_{3}^{-}$uptake and 1 with culture without label for measurement of $\mathrm{pH}$ at the end of the time point. Care was taken to avoid an air space in the vials. One set of vials was placed on a shaker table and the other set was kept unmixed. Both sets were positioned in front of a light bank and were exposed to about $190 \mu$ Ein $\mathrm{m}^{-2} \mathrm{~s}^{-1}$. The mixed vials were vigorously shaken at $250 \mathrm{rpm}$. Timecourse measurements were made in experiments with 2 species (Stephanopyxis palmeriana and Thalassiosira weissfloggii) at $1,4,8,12$, and $24 \mathrm{~h}$. Five vials containing labeled culture and 5 with culture without label were used for each treatment (mixed vs unmixed) so that a whole vial could be sacrificed at each time point. Experiments with the remaining 3 species (Ditylum brightwellii, Coscinodiscus sp. and Odontalla mobviliensis) were terminated after $1 \mathrm{~h}$. Whole culture aliquots $(1 \mathrm{ml})$ were taken at each sampling point and placed directly into scintillation vials containing $2 \mathrm{ml}$ of methanol acidified with $5 \%$ glacial acetic acid. The vial contents were evaporated to dryness under an infra-red lamp, resuspended in $1 \mathrm{ml}$ distilled water, followed by addition of $10 \mathrm{ml}$ scintillation fluid (Handyfluor). Counts were then made on a Beckman LS 5000 TD liquid scintillation counter.

In a separate $\mathrm{pH}$-drift experiment replicate cultures of Ditylum brightwellii were grown in large Fernbach flasks in the environmental chamber, 1 kept unmixed and 1 mixed on the shaker table at $175 \mathrm{rpm}$. A Tefloncoated stir bar was placed in the mixed culture to enhance turbulence. Time-course sampling for cell counts, $\mathrm{pH}$ and $\mathrm{C}_{1}$ was carried out as in the previous $\mathrm{pH}$-drift experiments.

Chemical and biological measurements. Cell counts were made on samples preserved in Lugol's solution. Depending on the size of the species, counts were made with either a Spencer-Brightline hemocytometer, a Sedwick-Rafter slide or a $5 \mathrm{~cm}$ plastic Petri dish. Samples for $\mathrm{pH}$ and $\mathrm{C}_{\mathrm{t}}$ measurements were obtained by vacuum filtering $25 \mathrm{ml}$ of culture through GF/F filters (Whatman) under gentle vacuum $(\sim 25 \mathrm{~mm} \mathrm{Hg})$ to avoid degassing of free $\mathrm{CO}_{2}$. The filtrate was collected in $20 \mathrm{ml}$ glass vials attached directly under the exit stem of the filtration funnel. This allowed the vial to overflow with filtrate to minimize exposure to the air and eliminate an air space before the vial was removed from the filtration unit and sealed with a Teflon-lined screw cap. Separate vials were used for $\mathrm{pH}$ and $\mathrm{C}_{\mathrm{t}}$ measurements. The $\mathrm{C}_{\mathrm{t}}$ vials were either analyzed immediately or kept refrigerated until measurements were made, usually within several days of sampling. Measurements of $\mathrm{pH}$ were made immediately after sampling and filtration. Culture $\mathrm{pH}$ was measured on the NBS (National Bureau of Standards, Gaithersburg, MD, USA) scale with a Fisher Accumet combination probe and Model $825 \mathrm{MP}$ pH meter. Twopoint standardization of the probe was performed with pH 7.0 and 10.0 NBS buffers (Fisher). Temperature was compensated for manually by recording buffer and sample temperatures as part of the buffer standardization protocol. The probe was immersed in a sample for $10 \mathrm{~min}$ before the $\mathrm{pH}$ was recorded. Although the meter displayed $\mathrm{pH}$ to 3 decimal places, $\mathrm{pH}$ data were rounded off to 2 places.

$\mathrm{C}_{\mathrm{t}}$ was measured on a LiCor Model $6252 \mathrm{CO}_{2}$ Analyzer. Both temperature and barometric pressure were compensated for internally. A gas flow-through system was constructed consisting of a meter to maintain a continuous flow of carrier gas (ultra pure helium) at $120 \mathrm{ml} \mathrm{min}^{-1}$, a glass chamber for sample sparging, an ice bath for collecting water vapor, a dessicant filter, and micro-particle filters. The analyzer was programmed to integrate and record the mass flow of $\mathrm{CO}_{2}$. First, $0.1 \mathrm{ml}$ of a $5 \% \mathrm{H}_{3} \mathrm{PO}_{4}$ solution was injected through a rubber septum into the glass sparging chamber by syringe. Excess $\mathrm{CO}_{2}$ in the acid was sparged out of the system before the integration sequence began. Next, a $1 \mathrm{ml}$ sample was injected into the sparging chamber by syringe (Hamilton liquid-tight), $\mathrm{C}_{1}$ was converted to $\mathrm{CO}_{2}$ in the acidified sample, and the integrating sequence was started. The efficiency of $\mathrm{CO}_{2}$ extraction from $\mathrm{C}_{\mathrm{t}}$ in the liquid phase virtually was $100 \%$. The analyzer was calibrated with a range of standards from 0.25 to $2.5 \mathrm{mmol} \mathrm{l}^{-1} \mathrm{C}_{1}$ made from mixtures of $\mathrm{Na}_{2} \mathrm{CO}_{3}$ and $\mathrm{NaHCO}_{3}$. The resulting curve of meter reading versus $\mathrm{C}_{1}$ was fitted by non-linear regression analysis as a fifth-order polynomial.

Calculation of free $\mathrm{CO}_{2}$ concentration. Free $\mathrm{CO}_{2}$ concentration was determined from the equilibrium equations of the inorganic carbon system with $\mathrm{pH}$ and 
$C_{1}$ as the known variables (Stuum \& Morgan 1981). Following the approach of Crawford \& Harrison (1997). $\mathrm{pH}$ measurements made on the NBS scale ( $\mathrm{pH}_{\mathrm{NBS}}$ ) were first converted to $\mathrm{pH}$ on the seawater scale $\left(\mathrm{pH}_{\mathrm{SEA}}\right)$ using the relationship $\mathrm{pH}_{\mathrm{SEA}}=\mathrm{pH}_{\mathrm{NBS}}+\log f_{\mathrm{H}}$ in which $f_{\mathrm{H}}$ is the activity coefficient for hydrogen ion. The magnitude of $f_{H}$ is specific for each pH electrode and generally falls within a range of 0.70 to 0.85 (Mehrbach et al. 1973, Crawford \& Harrison 1997). Although Crawford \& Harrison (1997) obtained excellent agreement between measured and calculated values of free $\mathrm{CO}_{2}$ when $f_{\mathrm{H}}$ was assumed equal to 0.85 , in this study a more conservative value of 0.70 was assumed. With corrections for total fluoride and total sulfate (salinity $=35$, temp $=20^{\circ} \mathrm{C}$ ), $\mathrm{pH}_{\text {SEA }}$ was then converted to $\mathrm{pH}$ on the total scale ( $\mathrm{pH}_{\text {TOT }}$ ) and adjusted to $\mathrm{mol}$ ( $\mathrm{kg}$ solution) $^{-1}$ (Millero 1995). The resulting change from $\mathrm{pH}_{\mathrm{NBS}}$ to $\mathrm{pH}_{\text {TOT }}$ was $-0.12 \mathrm{pH}$ units. Hence, for the purposes of calculating free $\mathrm{CO}_{2}$ from $\mathrm{pH}$ and $\mathrm{C}_{t}$, all measured $\mathrm{pH}$ values were reduced by 0.12 . Then free $\mathrm{CO}_{2}$ was determined for each set of experimental $\mathrm{pH}$ and $\mathrm{C}_{\mathrm{t}}$ values, using recommended values for the equilibrium coefficients of the inorganic carbon system (DOE 1994).

Modeling pH-biomass relationships. A simple chemical-biological model was constructed to determine the effect of phytoplankton growth and resulting increases in biomass on pH (Stuum \& Morgan 1981). First, for a starting $\mathrm{pH}$, alkalinity was determined as:

$\left[A L K_{I}\right]=C_{t}\left(\alpha_{1}+2 \alpha_{2}\right)+\left[\mathrm{OH}^{-}\right]_{I}-\left[\mathrm{H}^{+}\right]_{I}+\left[\mathrm{B}\left(\mathrm{OH}^{-}\right)_{4}\right]_{\mathrm{I}}$

in which $\left[\mathrm{ALK}_{\mathrm{I}}\right]$ is the initial alkalinity in eq $\mathrm{l}^{-1},\left[\mathrm{OH}^{-}\right]_{1}$ and $\left[\mathrm{H}^{+}\right]_{1}$ are, respectively, the hydroxyl and hydrogen ion concentrations in $\mathrm{mol} \mathrm{I}^{-1}$ for the initial $\mathrm{pH}$, $\left[\mathrm{B}\left(\mathrm{OH}^{-}\right)_{4}\right]_{5}$ is the initial borate concentration in $\mathrm{mol} \mathrm{l}^{-1}$, and $\alpha_{1}+\alpha_{2}$ are the ionization fractions for $\mathrm{HCO}_{3}^{-}$and $\mathrm{CO}_{3}{ }^{2-}$, respectively, as a function of $\mathrm{pH}$. These coefficients are defined as:

and

$$
\begin{aligned}
& \alpha_{1}=\left(1+\left[\mathrm{H}^{+}\right] / K_{1}+K_{2} /\left[\mathrm{H}^{+}\right]\right)^{-1} \\
& \alpha_{2}=\left(\left[\mathrm{H}^{+}\right]^{2} / K_{1} K_{2}+\left[\mathrm{H}^{+}\right] / K_{2}+1\right)^{-1}
\end{aligned}
$$

in which $K_{1}$ and $K_{2}$ are the equilibrium coefficients of the inorganic carbon system in mol $\mathrm{I}^{-1} \cdot\left[\mathrm{B}\left(\mathrm{OH}^{-}\right)_{4}\right]_{1}$ can be expressed as $\mathrm{B}_{\mathrm{T}} K_{\mathrm{B}} /\left(\left[\mathrm{H}^{+}\right]_{\mathrm{I}}+K_{\mathrm{B}}\right)$ in which $\mathrm{B}_{\mathrm{T}}$ is the total boric acid concentration in seawater and $K_{\mathrm{B}}$ is the dissociation coefficient for boric acid. Both $\mathrm{B}_{\mathrm{T}}$ and $K_{\mathrm{B}}$ can be estimated for known salinity and temperature (Millero 1995). Changes in $C_{t}\left(\Delta C_{t}\right)\left(m o l ~^{-1} d^{-1}\right)$ due solely to phytoplankton growth were estimated by the relationship:

$$
\Delta \mathrm{C}_{\mathrm{t}}=Q_{\mathrm{C}} X_{0}\left(\mathrm{e}^{\mu t}-1\right)
$$

in which $Q_{C}$ is the carbon cell quota (mol cell ${ }^{-1}$ ), $X_{0}$ is initial cell concentration (cells $\mathrm{F}^{-1}$ ), $\mu$ is the specific growth rate $\left(\mathrm{d}^{-1}\right)$, and $t$ is the duration of the growth period (d).
The final alkalinity $\left(A L K_{F}\right)$ resulting from phytoplankton growth, while not changed by inorganic carbon uptake, is increased by both $\mathrm{NO}_{3}{ }^{-}$and $\mathrm{HPO}_{4}{ }^{2-}$ uptake (Brewer \& Goldman 1976, Stuum \& Morgan 1981). Using a Redfield stoichiometry of $\mathrm{C}_{106} \mathrm{~N}_{16} \mathrm{P}_{1}$ for phytoplankton biomass, the change in alkalinity was calculated as:

$$
\mathrm{ALK}_{\mathrm{F}}=\mathrm{ALK}_{\mathrm{I}}+(18 / 106) \mathrm{C}_{\mathrm{t}}
$$

The factor $18 / 106$ is derived from the fact that at the $\mathrm{pH}$ of seawater, $\mathrm{HPO}_{4}{ }^{2-}$ is the dominant form of phosphate. Thus to maintain charge balance in the photosynthetic reaction, $18 \mathrm{~mol}$ of $\mathrm{OH}^{-}$are produced for each mole of organic matter produced in the form $\mathrm{C}_{106} \mathrm{~N}_{16} \mathrm{P}_{1}$.

$A L K_{F}$ can also be expressed as

$$
\begin{aligned}
\mathrm{ALK}_{\mathrm{F}} & =\left(\mathrm{C}_{\mathrm{l}}-\Delta \mathrm{C}_{\mathrm{l}}\right)\left(\alpha_{1}+2 \alpha_{2}\right) \\
& +[\mathrm{OH}]_{\mathrm{F}}^{-}\left[\mathrm{H}^{+}\right]_{\mathrm{F}}+\mathrm{B}_{\mathrm{T}} K_{\mathrm{B}} /\left(\left[\mathrm{H}^{+}\right]_{\mathrm{F}}+K_{\mathrm{B}}\right)
\end{aligned}
$$

Eq. (6) was simplified by determining $A_{F} K_{F}$ from Eq. (5) and $\Delta C_{1}$ from Eq. (4) for known values of $A L K_{I}$ (from Eq. 1), $\mathrm{C}_{1}, \mu, Q_{\mathrm{C}}, X_{0}, \mathrm{~B}_{\mathrm{T}}, K_{1}, K_{2}, K_{\mathrm{B}}$, salinity and temperature and inserting them into the equation. Then $\mathrm{pH}_{\mathrm{F}}$ (final $\mathrm{pH}$ ) was determined as a function of time by varying $\mathrm{H}^{+}$in an iterative process until Eq. (6) was solved for each value of $t$. By assuming different growth scenarios, it was possible to gauge the impact of phytoplankton growth on seawater $\mathrm{pH}$ and to compare these results with grow th conditions typically found in oceanic waters.

\section{RESULTS}

\section{pH drift experiments}

Growth rates of the 3 test species (Stephanopyxis palmeriana, Coscinodiscus sp., and Ditylum brightwellin) remained constant for extended periods in the static $\mathrm{pH}$ drift experiments while the $\mathrm{pH}$ rose and the free $\mathrm{CO}_{2}$ concentration fell (Fig. 1). Levels of $\mathrm{pH}$ as high as 8.45 and 8.51 , corresponding to minimum free $\mathrm{CO}_{2}$ concentrations of 4.4 and $3.7 \mu \mathrm{mol} \mathrm{l} \mathrm{l}^{-1}$, were observed, respectively, in the cultures of $S$. palmeriana (Fig. 1D) and D. brightwellii (Fig. 1F) before $\mu$ decreased. For Coscinodiscus sp., pH rose to a lower level than in the other 2 cultures mentioned above (8.31) and, free $\mathrm{CO}_{2}$ decreased to $7.1 \mu \mathrm{mol} \mathrm{l^{-1 }}$ before a decrease in $\mu$ was noted (Fig. 1E). There was no correlation between changes in $\mathrm{pH}$ or free $\mathrm{CO}_{2}$ and $\mu$ or cell size: $D$. brightwellii displayed the highest $\mu\left(1.20 \mathrm{~d}^{-1}\right.$; Fig. 1C), followed by Coscinodiscus sp $\left(0.90 \mathrm{~d}^{-1}\right.$; Fig 1B) and $S$. palmeriana $\left(0.50 \mathrm{~d}^{-1}\right.$; Fig. 1A) (Table 1).

Mixing had no impact on enhancing $\mu$ in a separate $\mathrm{pH}$-drift experiment with Ditylum brightweillii (Fig. 2) 
Fig. 1 Time course of growth, $\mathrm{pH}$ and free $\mathrm{CO}_{2}$ changes during balch $\mathrm{pH}$-drift experiments with large marine diatoms. (A,D) Stephanopyxis palmeriana; $(\mathrm{B}, \mathrm{E})$ Coscinodiscus sp.; (C,F) Ditylum brightwellii. $(A-C)$ Changes in cell number; $(\mathrm{D}-\mathrm{F})$ changes in $\mathrm{pH}$ $(\bullet)$, and free $\mathrm{CO}_{2}$ concentration (o). Curves in all figures (except linear portion of changes in cell number) were drawn by visual inspection to show trends only. Linear portion of changes in cell number was determined by regression analyses (same for Figs. 2 \& 3 )
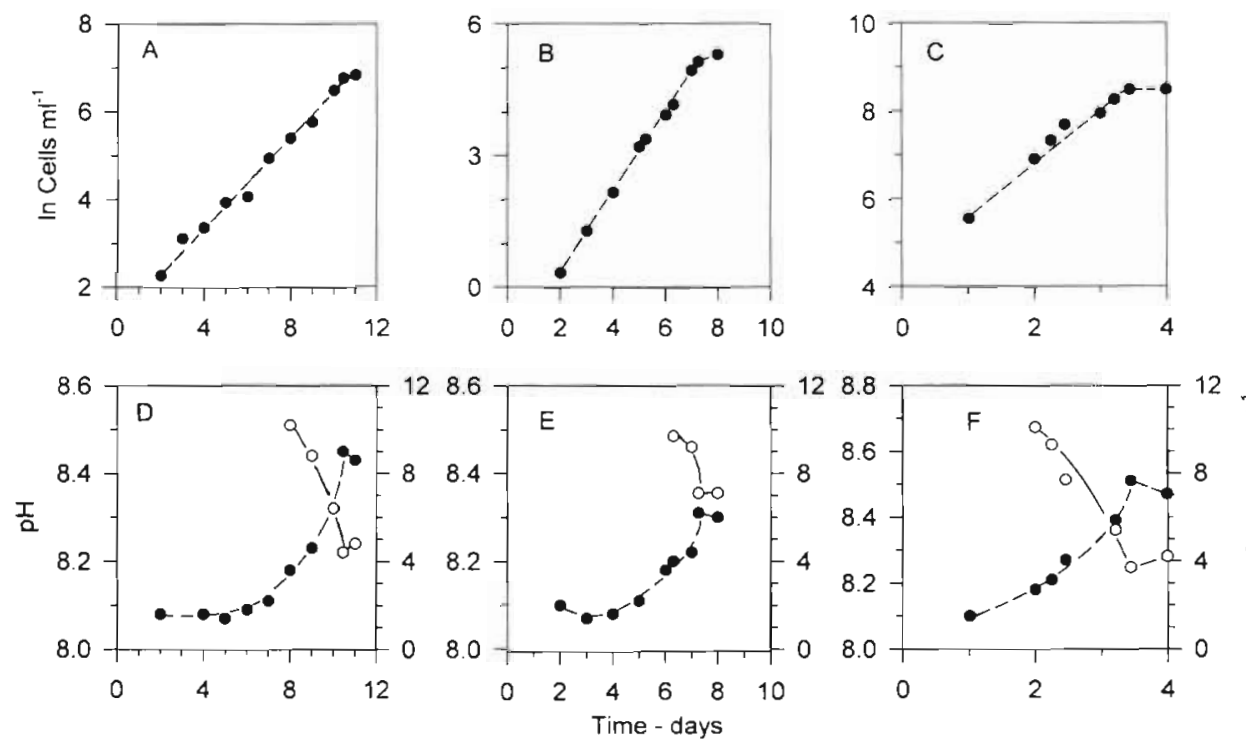

After a few days of lag growth, growth rates were exponential and virtually identical in unmixed $\left(1.91 \mathrm{~d}^{-1}\right.$; Fig. 2A) and mixed cultures $\left(1.88 \mathrm{~d}^{-1}\right.$; Fig. 2B) (Table 1). However, the maximum $\mathrm{pH}$ was higher (8.54) and the minimum free $\mathrm{CO}_{2}$ concentration lower $\left(3.2 \mu \mathrm{mol} \mathrm{l}^{-1}\right)$ in the unmixed culture (Fig. 2C) compared to the mixed culture (maximum $\mathrm{pH}=8.24$, minimum free $\mathrm{CO}_{2}$ concentration $=8.6 \mu \mathrm{mol} \mathrm{l}^{-1}$; Fig. 2D) (Table 1). The lower $\mathrm{pH}$ in the mixed culture was attributed to enhanced gas exchange with the atmosphere.

\section{Turbulence experiments}

Initial growth rates of Stephanopyxis palmeriana and Thalassiosira weissfloggii before the $24 \mathrm{~h} \mathrm{H}^{14} \mathrm{CO}_{3}$ uptake studies commenced in the presence and $a b$ sence of mixing were, respectively, 0.81 and $1.14 \mathrm{~d}^{-1}$ (Fig. 3A, B). Rates of $\mathrm{H}^{14} \mathrm{CO}_{3}$ uptake of unmixed and mixed samples from both cultures were constant during the first $12 \mathrm{~h}$ of the $24 \mathrm{~h}$ incubation: $317 \mu \mathrm{mol}$ $C \mathrm{~d}^{-1}$ (both unmixed and mixed) for $S$. palmeriana (Figs. 3C \& 4) and 812 (unmixed) versus $815 \mu \mathrm{mol} \mathrm{C} \mathrm{d}{ }^{-1}$ (mixed) for $T$. weissfloggii (Figs. 3D \& 4). Based on linear regression analyses, $r^{2}$ was 0.98 to 0.99 for all curves up to $12 \mathrm{~h}$ incubation. Beyond $12 \mathrm{~h}$ incubation carbon uptake rates decreased for all samples. During the initial $12 \mathrm{~h}$ period free $\mathrm{CO}_{2}$ concentrations dropped from 8.3 to $5.1 \mu \mathrm{mol} \mathrm{l}^{-1}$ and the $\mathrm{pH}$ rose from 8.26 to 8.41 for $S$. palmeriana (Fig. 3E) and from 2.2 to $0.4 \mathrm{\mu mol} \mathrm{l}^{-1}$ and 8.66 to 9.09 for T. weissfloggii (Fig. 3F) (Table 1).

Table 1. Summary of species size and experimental design and results. Turbulence experiment: $\mathrm{pH}$-drift followed by $1 \mathrm{~h}$ or $24 \mathrm{~h}$ $\mathrm{H}^{14} \mathrm{CO}_{3}^{-}$uptake experiment; $\mathrm{H}^{14} \mathrm{CO}_{3}^{-}$uptake experiment initiated before maximum $\mathrm{pH}$ attained; values given in parentheses were taken at end of $12 \mathrm{~h} \mathrm{H}^{14} \mathrm{CO}_{3}^{-}$uptake experiment

\begin{tabular}{|c|c|c|c|c|c|}
\hline Species & $\begin{array}{c}\text { Dimensions } \\
\quad(\mu \mathrm{m})\end{array}$ & Expt & $\begin{array}{c}\mu \\
\left(d^{-1}\right)\end{array}$ & Max. pH & $\begin{array}{l}\text { Min. } \mathrm{CO}_{2} \\
\left(\mu \mathrm{mol} \mathrm{l^{-1 }}\right)\end{array}$ \\
\hline Stephanopyxis palmeriana & $50 \times 100-120$ & $\begin{array}{l}\text { pH-drift } \\
\text { Turbulence }\end{array}$ & $\begin{array}{l}0.50 \\
0.81\end{array}$ & $\begin{array}{c}8.45 \\
8.26(8.41)\end{array}$ & $\begin{array}{c}4.4 \\
8.3(5.1)\end{array}$ \\
\hline Coscinodiscus sp. & $70-80 \times 60-65$ & $\begin{array}{l}\text { pH-drift } \\
\text { Turbulence }\end{array}$ & $\begin{array}{l}0.90 \\
0.74\end{array}$ & $\begin{array}{l}8.31 \\
8.21\end{array}$ & $\begin{array}{l}7.1 \\
9.3\end{array}$ \\
\hline Ditylum brightwellii & $20-40 \times 60-80$ & $\begin{array}{l}\text { pH-drift } \\
\text { Turbulence } \\
\text { pH-drift (static) } \\
\text { pH-drift (mixed) }\end{array}$ & $\begin{array}{l}1.20 \\
1.56 \\
1.91 \\
1.88\end{array}$ & $\begin{array}{l}8.51 \\
8.42 \\
8.54 \\
8.24\end{array}$ & $\begin{array}{l}3.7 \\
5.0 \\
3.2 \\
8.6\end{array}$ \\
\hline Odontella mobiliensis & $35-50 \times 55-80$ & Turbulence & 0.37 & 8.20 & 9.9 \\
\hline Thalassiosira weissfloggii & $12 \times 20$ & Turbulence & 1.14 & $8.66(9.09)$ & $2.2(0.4)$ \\
\hline
\end{tabular}



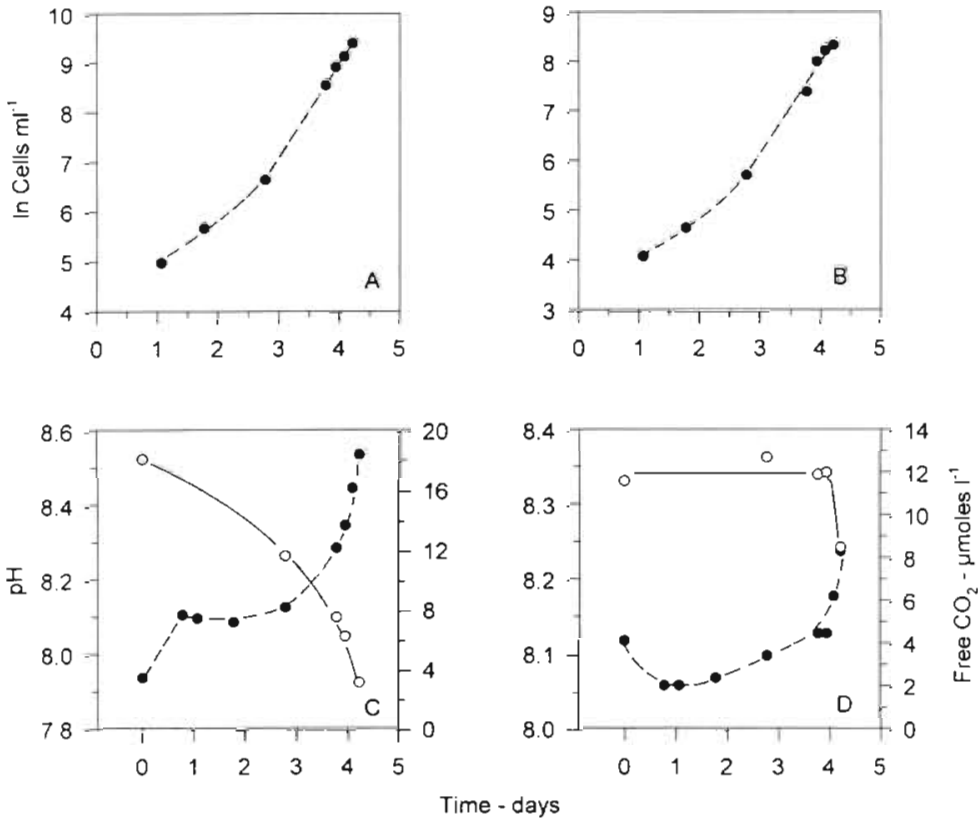

Fig. 2. Ditylum brightwellii. Time course of growth, $\mathrm{pH}$ and free $\mathrm{CO}_{2}$ changes during batch $\mathrm{pH}$-drift experiment. $(\mathrm{A}, \mathrm{C})$ static; $(B, D)$ mixed. $(A, B)$ Changes in cell number; $(C, D)$ changes in $\mathrm{pH}(\bullet)$ and free $\mathrm{CO}_{2}$ concentration (o)
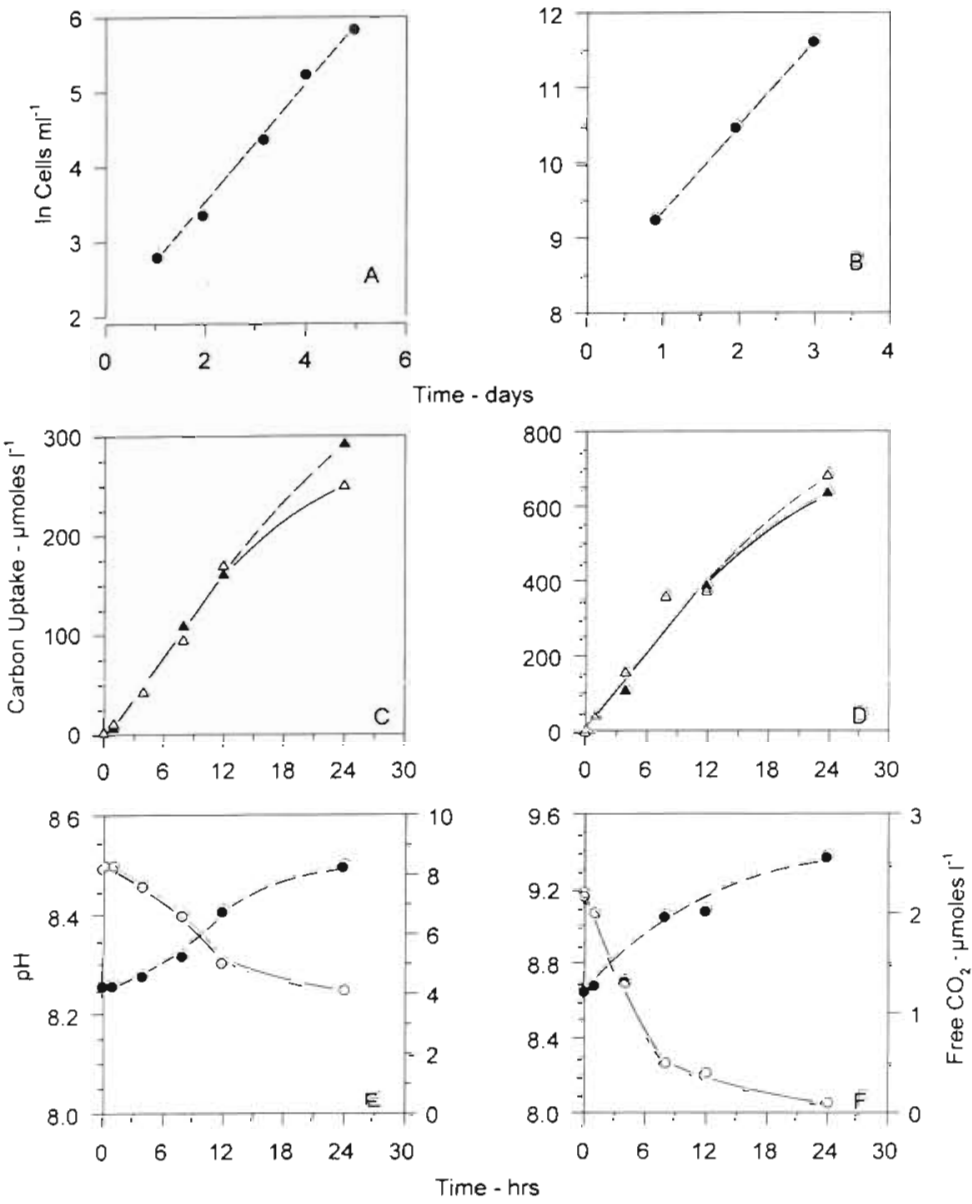

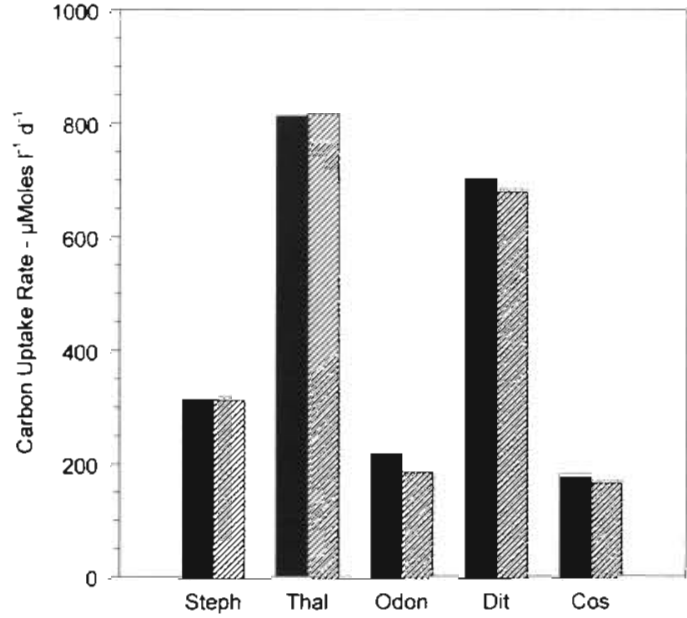

Fig. 4. Time series $\mathrm{H}^{14} \mathrm{CO}_{3}{ }^{-}$uptake of large marine diatoms: static (solid bar), mixed (shaded bar). Rate from slope of uptake curve from $24 \mathrm{~h}$ time series study shown in Fig. 3: Stephanopyxis palmeriana (Steph), Thalassiosira weissfloggii (Thal); $1 \mathrm{~h}$ rate from single-end-point measurement: Odontella mobiliensis (Odon), Ditylum brightwellii (Dit), Coscinodiscus sp. (Cos)

Growth rates of cultures used for the $1 \mathrm{~h}$ incubations were $0.74 \mathrm{~d}^{-1}$ for Coscinodiscus sp., $1.56 \mathrm{~d}^{-1}$ for Ditylum brightwellii and $0.37 \mathrm{~d}^{-1}$ for Odontella mobiliensis (Table 1). As during the $12 \mathrm{~h}$ incubations, there was virtually no difference in carbon uptake rates for unmixed and mixed samples for the 3 species (Fig. 4). Also, both free $\mathrm{CO}_{2}$ concentration and $\mathrm{pH}$ remained unchanged during the short $1 \mathrm{~h}$ incubations for all 3 species, whether mixed or unmixed. Free $\mathrm{CO}_{2}$ concentration and $\mathrm{pH}$ were, respectively, $9.3 \mu \mathrm{mol} \mathrm{l}^{-1}$ and 8.21 for Coscinodiscus sp., $5.0 \mu \mathrm{mol} \mathrm{l}^{-1}$ and 8.42 for $D$. brightwellii, and $9.9 \mu \mathrm{mol} \mathrm{l}^{-1}$ and 8.20 for $O$. mobiliensis (Table 1).

\section{Effect of growth on $\mathrm{pH}$}

Two growth scenarios similar to those of the current experiments were modeled according to Eqs. (4) to (6), one with Stephanopyxis palmeriana and the other with Thalassiosira weisfloggii. For S. palmeriana the

Fig. 3. Time course of growth during batch pH-drift phase and $\mathrm{H}^{14} \mathrm{CO}_{3}^{-}$uptake, $\mathrm{pH}$ and free $\mathrm{CO}_{2}$ concentration during short-term mixing phase with large marine diatoms. $(\mathrm{A}, \mathrm{C}, \mathrm{E})$ Stephanopyxis palmeriana $(\mathrm{B}, \mathrm{D}, \mathrm{F})$ Thalassiosira weissfloggii. $(A, B)$ Changes in cell number; $(C, D)$ time series carbon $\left(\mathrm{H}^{14} \mathrm{CO}_{3}^{-}\right)$uptake: static $(\Delta)$, mixed $(\Delta)$; $(\mathrm{E}, \mathrm{F})$ changes in $\mathrm{pH}(\bullet)$ and free $\mathrm{CO}_{2}$ concentration (o) (static and mixed were identical) 
effect of growth on $\mathrm{pH}_{F}$ (final $\mathrm{pH}$ ) was examined for 2 initial values of $\mathrm{pH}\left(\mathrm{pH}_{1}=8.1,8.2\right)$, an initial cell number $X_{0}$ of 1600 cells $\mathrm{I}^{-1}$ and a specific growth rate $\mu$ of $0.8 \mathrm{~d}^{-1}$ (from Table 1). Values of $20^{\circ} \mathrm{C}$ for temperature, 35 for salinity, and $2.3 \mathrm{mmol} \mathrm{l}^{-1}$ for $\mathrm{C}_{1}$ were assumed and $Q_{c}\left(5000 \mathrm{pg}\right.$ cell $\left.{ }^{-1}\right)$ and cellular chlorophyll a (chl a) (120 pg cell $\left.{ }^{-1}\right)$ for this species were obtained from a previous study (Goldman et al. 1992). From the resulting curves of increasing biomass levels (represented by chl a) (Fig. 5A) and $\mathrm{pH}_{\mathrm{F}}$ (Fig. 5B) and decreasing free $\mathrm{CO}_{2}$ concentration (Fig. $5 \mathrm{C}$ ) over time, it is obvious that only when the chl a concentration rises above $\sim 10 \mu \mathrm{g} \mathrm{l}^{-1}$ are there appreciable changes in $\mathrm{pH}$ and free $\mathrm{CO}_{2}$ concentration from the starting

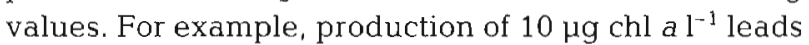
to a $\mathrm{pH}$ increase of only $<0.1 \mathrm{pH}$ units for both values of $\mathrm{pH}_{\mathrm{I}}$ and a reduction in free $\mathrm{CO}_{2}$ concentrations to $\sim 10.4 \mu \mathrm{mol} \mathrm{l}^{-1}$ for $\mathrm{pH}_{1}$ of 8.1 and $8.2 \mu \mathrm{mol} \mathrm{l}^{-1}$ for $\mathrm{pH}_{1}$
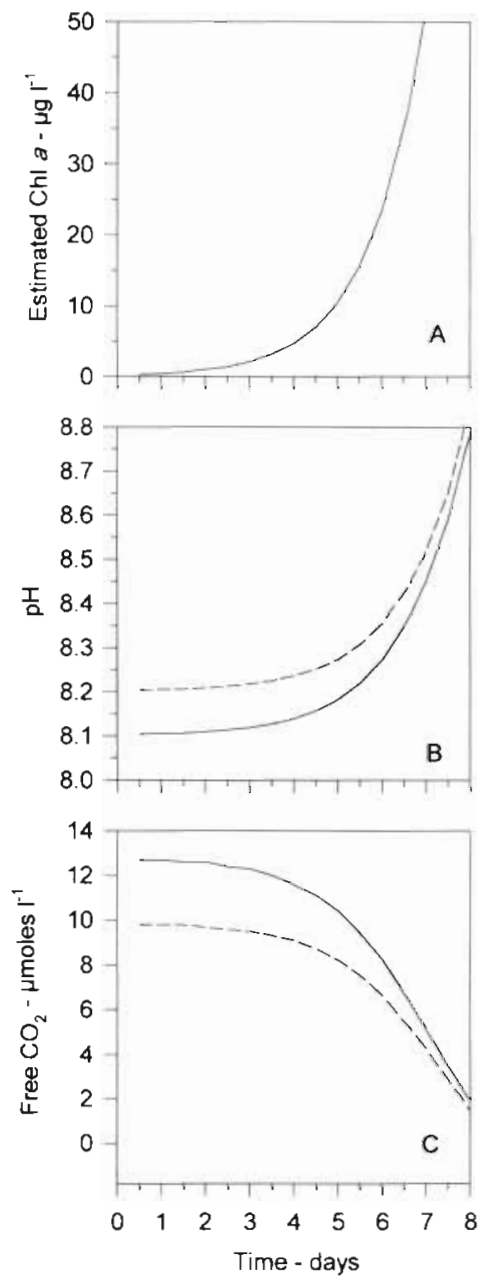

Fig. 5. Stephanopyxis palmeriana. Model scenario of effects of growth for different starting $\mathrm{pH}$ values $\left(\mathrm{pH}_{\mathrm{I}}\right)$ on $(\mathrm{A}) \mathrm{chl} a$, (B) $\mathrm{pH}_{F}$ and $(\mathrm{C})$ free $\mathrm{CO}_{2}$ concentration. $(\mathrm{B}, \mathrm{C})-\mathrm{pH}_{1}=8.1$; - : $\mathrm{pH}_{1}=8.2$. See text for growth conditions
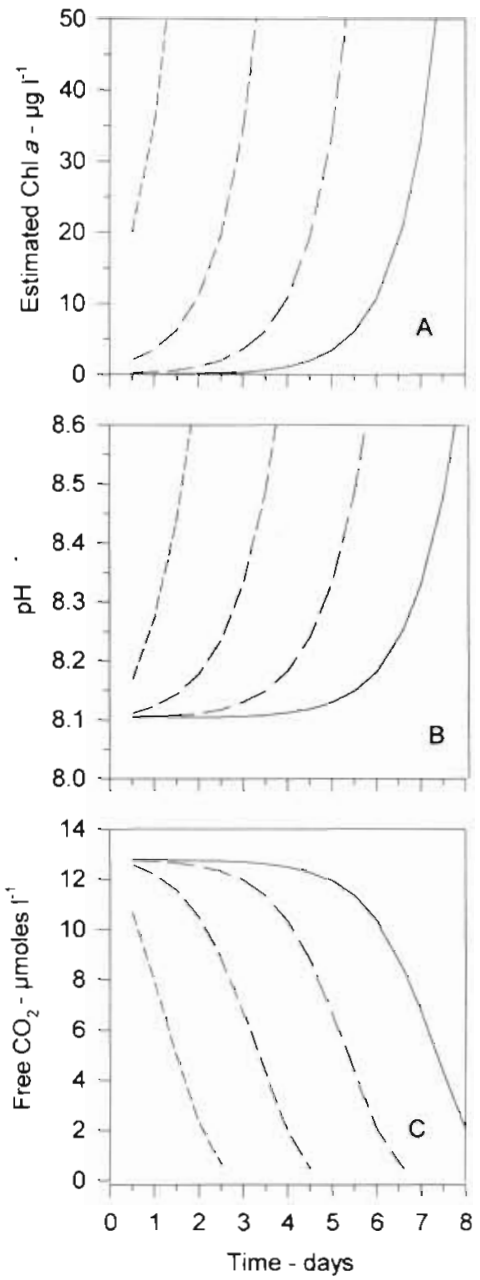

Fig. 6. Thalassiosira weissfloggii. Model scenario of effects of growth for different starting cell concentrations $\left(X_{0}\right)$ on $(A)$ chl $a_{1}$ (B) $\mathrm{pH}_{\mathrm{F}}$ and (C) free $\mathrm{CO}_{2}$ concentration - - - $X_{0}=2 \times$ $10^{3}$ cells $\mathrm{ml}^{-1} ;-\ldots: X_{0}=2 \times 10^{4}$ cells ml $^{-1} ;-\ldots-X_{0}=2 \times$ $10^{5}$ cells $\mathrm{ml}^{-1}$; — : $X_{0}=2 \times 10^{6}$ cells $\mathrm{ml}^{-1}$ See text for growth conditions

of 8.2 . In contrast, production of $50 \mu \mathrm{g} \mathrm{chl} \mathrm{a} 1^{-1}$ results in an increase of $\sim 0.35 \mathrm{pH}$ units for both $\mathrm{pH}_{\mathrm{I}}$ values so that $\mathrm{pH}_{\mathrm{F}}$ increases to $\sim 8.45$ or $\sim 8.55$ and the free $\mathrm{CO}_{2}$ concentration decreases to $\sim 5$ or $\sim 4 \mu \mathrm{mol} \mathrm{l}^{-1}$ when $\mathrm{pH}_{\mathrm{I}}$ is 8.1 or 8.2 .

Growth conditions for the second scenario involving Thalassiosira weisfloggii included $\mu=1.14 \mathrm{~d}^{-1}$ (from Table 1), $\mathrm{pH}_{1}=8.1$, and the same temperature, salinity, and $C_{t}$ as in the previous scenario. For this case, however, the aim was to determine the impact on $\mathrm{pH}_{\mathrm{F}}$ of varying $X_{0}$, in this case over a span of 3 orders of magnitude from $2 \times 10^{3}$ to $2 \times 10^{6}$ cells l $^{-1}$. Estimates of $Q_{c}$ $\left(226 \mathrm{pg} \mathrm{cell}^{-1}\right)$ and cellular chl a $\left(5.65 \mathrm{pg} \mathrm{cell}^{-1}\right)$ for this species also came from a previous study (Goldman \& Glibert 1982). The results obtained were strikingly similar to those involving Stephanopyxis palmeriana. 
Only when chl a levels exceeded $\sim 10 \mu \mathrm{g} \mathrm{l}^{-1}$ (Fig. 6A) were there appreciable changes in $\mathrm{pH}$ (Fig. 6B) and free $\mathrm{CO}_{2}$ concentration (Fig. 6C). The starting cell number had little effect on these results, only the time it took to achieve these changes. At chl a levels of $10 \mu \mathrm{g} \mathrm{l}^{-1}$ the increase in $\mathrm{pH}$ was $<0.1 \mathrm{pH}$ units, whereas at $50 \mathrm{\mu g} \mathrm{l}^{-1}$ the increase was $\sim 0.35 \mathrm{pH}$ units $\left(\mathrm{pH}_{\mathrm{F}}-8.45\right)$. Correspondingly, the free $\mathrm{CO}_{2}$ concentrations fell to about 11 and $6 \mu \mathrm{mol} \mathrm{l}^{-1}$ at these chl a levels.

\section{DISCUSSION}

\section{Free $\mathrm{CO}_{2}$ requirements for growth}

In the context of trying to interpret the data from the $\mathrm{pH}$-drift and turbulence experiments and to determine the conditions that might favor limitation by free $\mathrm{CO}_{2}$ of phytoplankton growth rates in seawater it is necessary to consider 2 essential points. First, in $\mathrm{C}_{3}$ plants, which include marine phytoplankton, free $\mathrm{CO}_{2}$ is required internally in the initial reaction of the photosynthetic process. The enzyme ribulose biphosphate carboxylase-oxygenase (RUBISCO), which catalyzes this reaction, has a rather high half saturation coefficient $\left(K_{S}\right)$ for $\mathrm{CO}_{2}$, about 25 to $40 \mu \mathrm{mol} \mathrm{l} \mathrm{l}^{-1}$ for green algae and diatoms and 100 to $120 \mu \mathrm{mol} \mathrm{l^{-1 }}$ for cyanobacteria (Jordan \& Ogren 1981, Read \& Tabita 1994). And, second, it is well documented that $K_{S}$ values for free $\mathrm{CO}_{2}$ uptake by numerous marine phytoplankton species typically are below 1 to $2 \mu \mathrm{mol} \mathrm{l}^{-1}$ (Raven \& Johnson 1991).

Thus in order to reconcile the great difference in the magnitudes of the $2 K_{S}$ values and to avoid $\mathrm{CO}_{2}$ limitation of photosynthesis there must be some mechanism for elevating the free $\mathrm{CO}_{2}$ concentration at the site where RUBSICO is located. Indeed, from both the plant physiology and marine biology literature, there is now substantial evidence that many different species, including marine diatoms, have the ability to concentrate free $\mathrm{CO}_{2}$ internally (Lucas \& Berry 1985, Burns \& Beardall 1987, Munoz \& Merrett 1989, Badger \& Price 1992, Korb et al. 1997, Nimer et al. 1997, Torteil et al. 1997). The process is believed to occur either by the facilitated conversion of $\mathrm{HCO}_{3}^{-}$to $\mathrm{CO}_{2}$ externally, followed by transport of $\mathrm{CO}_{2}$ into the cell, or by the active uptake of $\mathrm{HCO}_{3}^{-}$into the cell, followed by conversion internally to $\mathrm{CO}_{2}$ (Badger \& Price 1992). The enzyme carbonic anhydrase plays a central role in catalyzing the conversion of $\mathrm{HCO}_{3}^{-}$to $\mathrm{CO}_{2}$ in both processes and is produced by the cell when the external free $\mathrm{CO}_{2}$ concentration is reduced below a critical level (Badger \& Price 1994). In comparing the low external free $\mathrm{CO}_{2}$ concentration in seawater at $\mathrm{pH}$ 8.1 to 8.2 with the high $K_{S}$ for $\mathrm{CO}_{2}$ of RUBISCO, it is easy to understand why the $\mathrm{CO}_{2}$ concentrating step is vital to prevent inorganic carbon limitation in marine phytoplankton, particularly in large species.

It is intuitively obvious that some mechanism for active uptake of inorganic carbon was occurring in the $\mathrm{pH}$-drift experiments and that free $\mathrm{CO}_{2}$ was not limiting growth of the 4 large diatoms. Otherwise, it would have been impossible to sustain constant growth rates as the free $\mathrm{CO}_{2}$ concentration dropped to levels 3 to 6 times lower than typical seawater values and 6 to 20 times lower than the $K_{S}$ for RUBISCO. Had these diatoms been obligate users of free $\mathrm{CO}_{2}$, then a reduction in $\mu$ should have occurred over this range of free $\mathrm{CO}_{2}$ concentrations. Given the large size of the 4 diatoms in the pH-drift experiments (Table 1) and the associated long diffusion paths, even lower free $\mathrm{CO}_{2}$ concentrations probably occurred at the sites of uptake. Such a diffusion constraint, had it existed, most likely would have been most severe in Stephanopyxis palmeriana, the largest of the test species. Individual cells of $S$. palmeriana, which are very large $(50 \times 100$ to $120 \mu \mathrm{m})$, grow in very long intertwined and overlapping chains (10s to 100 s of cells in length). The chains form loosely bound aggregates that are visible to the naked eye (Goldman 1993) and in the absence of liquid shear possess longer diffusion paths than single cells (Pahlow et al. 1997).

The fact that strong mixing had no effect on either growth (Fig. 2), or ${ }^{14} \mathrm{C}$ uptake (Figs. 3 \& 4) adds further support to the arguments that free $\mathrm{CO}_{2}$ was not controlling growth and that facilitated $\mathrm{HCO}_{3}{ }^{-}$uptake most likely was occurring. It is well established that the degree of turbulence that typically occurs in the oceans only benefits very large phytoplankton cells (>50 $\mu \mathrm{m}$ ) in breaking down diffusion barriers at the cell surface (Lazier \& Mann 1989, Karp-Boss et al. 1996). As pointed out by Karp-Boss et al. (1996), it is virtually impossible to simulate in the laboratory the form of turbulence present in the ocean, even with sophisticated 'Couette' type devices that allow measurement of shear rates. Thus to provide a simple qualitative demonstration of whether or not phytoplankton growth rates could be enhanced by mixing, intense irregular mixing provided by a shaker table operated at maximum speeds was used. Mixing experiments of this type have been used successfully in the past by Pasciak \& Gavis (1975) to demonstrate the effects of diffusion in controlling nutrient uptake rates of Ditylum brightwellii, the same species as used in the current study. At speeds of $175 \mathrm{rpm}$ for the small glass vials and $250 \mathrm{rpm}$ for the larger Fernbach vessel, the shaker table was operated at close to its maximum attainable speeds. While it is impossible to quantify the degree of turbulence experienced in these vessels, it should have been greater than even the most intense levels found 
in the ocean, which are on the order of $\sim 10^{-2}-10^{-3} \mathrm{~cm}^{2}$ $\mathrm{s}^{-3}$ (Gargett 1989). Thus at least the 2 large species in this experiment (Stephanopyxis palmeriana and $D$. brightwellii), which were capable of drawing down the free $\mathrm{CO}_{2}$ concentration in the bulk fluid to $\left.\sim 5 \mu \mathrm{mol}\right]^{-1}$ when mixed (Table 1), should have experienced an increase in uptake of $\mathrm{CO}_{2}$ if they were obligate users of free $\mathrm{CO}_{2}$.

\section{pH and nutrient enrichment}

Given that the $\mathrm{C}_{\mathrm{t}}$ concentration is remarkably constant throughout the world's oceans at $-2.0-2.3 \mathrm{mmol}$ $\mathrm{I}^{-1}$, it is evident that $\mathrm{pH}$ is the major determinant of the free $\mathrm{CO}_{2}$ concentration in seawater. And, in turn, the magnitude of nutrient enrichment determines the level of phytoplankton biomass and, concomitantly, the resulting $\mathrm{pH}$ and free $\mathrm{CO}_{2}$ concentration of a growing cell population. Hence, because enrichment media for growing cultures in the laboratory generally contain nutrient concentrations far in excess of those found in even the most productive waters, it is expected that the final biomass and resulting $\mathrm{pH}$ of a growing laboratory culture will be considerably greater than that found in natural waters, even under bloom conditions. For example, enrichment media such as MET 44 can support levels of phytoplankton biomass that far exceed those found even in the most productive coastal upwelling and estuarine waters. Although chl a was not measured in the current study, multiplying the cell concentration of 664 cells $\mathrm{ml}^{-1}$ attained before $\mu$ decreased for Stephanopyxis palmeriana (Fig. 1A) by the cellular chl a quota of $120 \mathrm{pg} \mathrm{cell}{ }^{-1}$ for this species (from Goldman et al. 1992), leads to a chl a production of $\sim 80 \mu \mathrm{g} \mathrm{l}^{-1}$. This chl a concentration is almost identical to what was attained for $S$. palmeriana and other large diatoms grown on MET 44 medium in experiments similar to the current ones (Goldman et al. 1992). It exceeds the chl a concentration typically found in highly productive upwelling and estuarine waters (up to $\sim 10-25 \mu \mathrm{\mu g} \mathrm{1^{-1 }}$ ) by up to an order of magnitude and in oceanic waters $\left(-0.05-0.1 \mu \mathrm{g} \mathrm{l}^{-1}\right)$ by several orders of magnitude (Chavez et al. 1996, Cloern 1996, Wells pers. comm.). The results from the modeling exercises (Figs. 5 \& 6), in which at least $50 \mu \mathrm{g}$ $\mathrm{l}^{-1}$ chl a was required before the $\mathrm{pH}$ and free $\mathrm{CO}_{2}$ concentration of seawater approached levels where reductions in growth rate might occur, highlight this point. Simply, such biomass levels, while common in enriched laboratory cultures, are never found in the ocean.

If the responses of the large diatoms in the current experiments are representative of indigenous species then it is unlikely that free $\mathrm{CO}_{2}$ concentration has much, if any, influence on growth rates of marine phytoplankton, since the large diatoms, because of their long diffusion paths, represent the worst case scenario. This conclusion leads to the important point that in trying to use results from laboratory experiments to infer the conditions under which free $\mathrm{CO}_{2}$ might limit marine phytoplankton growth in natural waters it is necessary to compare not only biomass levels of the 2 systems, but the $\mathrm{pH}$ and free $\mathrm{CO}_{2}$ concentration as well. While good $\mathrm{pH}$ data are lacking for oceanic waters, there are an abundance of high quality free $\mathrm{CO}_{2}$ data, showing that the $\mathrm{pCO}_{2}$ concentration in the world's oceans rarely falls below $200 \mu \mathrm{atm}$ (equivalent to $6.5 \mu \mathrm{mol} \mathrm{l}^{-1}$ free $\mathrm{CO}_{2}$ at $20^{\circ} \mathrm{C}$ ) and most often is between 300 and $400 \mu \mathrm{atm}$ (9.7 to $12.9 \mathrm{\mu mol} \mathrm{l}^{-1}$ free $\mathrm{CO}_{2}$ at $20^{\circ} \mathrm{C}$ ) (Landrum et al. 1994, Robertson et al. 1994, Bates et al. 1996, Cooper et al. 1998, Wanninkhof \& Feely 1998). Much of the variability is related to physical phenomena such as temperature, wind speed, and mixing, but in some productive locales, such as the northeast Atlantic where coccolithophore blooms are common and in the Bering Sea during the spring bloom, decreases in $\mathrm{pCO}_{2}$ down to 150 to 200 patm have been measured (Codspoti et al. 1986, Cooper et al. 1994, Robertson et al. 1994). However, even the lowest $\mathrm{pCO}_{2}$ levels measured in such regions are above the $\mathrm{CO}_{2}$ levels associated with reductions in $\mu$ of the large diatoms from the current study, which were about 2 to $4 \mu \mathrm{mol} \mathrm{l}^{-1}$ (equivalent to 60 to $120 \mu$ atm at $20^{\circ} \mathrm{C}$ ).

\section{ECOLOGICAL PERSPECTIVE}

It is important to note that the levels of $\mathrm{pH}$ and free $\mathrm{CO}_{2}$ concentration at which $\mu$ began to decrease in the current experiments were not necessarily the result of free $\mathrm{CO}_{2}$ limitation. Although such a conclusion has been inferred previously by Riebesell et al. (1993) and Chen \& Durbin (1994) in experiments where pH and free $\mathrm{CO}_{2}$ concentration were co-varied, it is virtually impossible to draw any conclusions about free $\mathrm{CO}_{2}$ effects on $\mu$ unless $\mathrm{pH}$ is held constant. Both adverse physiological responses and reduced availability of sparingly soluble and essential macro- and micronutrients at higher $\mathrm{pH}$ could impact on growth. What is most important, however, is that, in order to observe a reduction in growth rate in the current experiments, a $\mathrm{pH}$ level of about 8.5 to 8.7 was necessary for the large diatoms. Similar results were obtained by Riebesell et al. (1993) and Chen \& Durbin (1994) in experiments involving other marine diatom species, although they did not conclude, as in this study, that such conditions are mainly restricted to enrichment cultures. As stated previously, such extreme $\mathrm{pH}$ levels and correspond- 
ingly low $\mathrm{CO}_{2}$ concentrations never occur in the ocean, except perhaps during exceptional blooms in isolated coastal and estuarine environments.

In conclusion, the seemingly widespread ability of marine phytoplankton to utilize $\mathrm{HCO}_{3}^{-}$, in principle, allows full utilization of the reservoir of inorganic carbon in oceanic waters. Thus it is necessary to look to other more sparingly available nutrients as controlling factors of marine primary productivity. The recent interest in iron as a limiting nutrient in some regions of the world's ocean has highlighted the possibility that low levels of other trace metals may also play a role in regulating productivity. For example, zinc (a co-factor in carbonic anhydrase, the enzyme necessary for $\mathrm{HCO}_{3}{ }^{-}$uptake), like iron, is found in potentially limiting concentrations in some regions of the ocean (Bruland 1989). Morel et al. (1994) have shown in laboratory studies that limiting levels of zinc indirectly influence inorganic carbon uptake by the diatom Thalassiosira weissfloggii through effects on carbonic anhydrase activity. A similar effect was found in other, but not all, marine phytoplankton species by Lee \& Morel (1995). In addition, it was found that cadmium and cobalt can in part substitute for zinc (Price \& Morel 1990, Lee \& Morel 1995, Sunda \& Huntsman 1995).

In the current study the only trace metals purposely added to Sargasso seawater were iron and manganese. However, neither clean techniques nor purified reagents were used in the preparation of the medium and inadvertent contamination by zinc likely occurred, thereby negating any possible influence of this metal on the activity of carbonic anhydrase and concomitantly on growth rate as a function of increasing $\mathrm{pH}$. Nonetheless, it is virtually impossible to draw any conclusions about how trace metals might have impacted on phytoplankton growth in the present study, given the enormous complexities of trace metal interaction and regulation of phytoplankton growth (Hudson \& Morel 1993). From an ecological standpoint it would seem that oceanic phytoplankton have evolved the ability to utilize $\mathrm{HCO}_{3}{ }^{-}$in some fashion as a means of avoiding limitation by free $\mathrm{CO}_{2}$. Whether a similar evolutionary adaptation exists for coping with low levels of trace metals in oceanic waters, and how it might impact on inorganic carbon acquisition by marine phytoplankton, remains to be determined. While such questions were beyond the scope of the present study, they are worthy of considerable future research.

Acknowledgements. I thank Linda Davis for her expert technical assistance and Ken Bruland and Mark Wells for their critical reviews of the manuscript. This study was supported by grant No. OCE-9416012 from the National Science Foundation.

\section{LITERATURE CITED}

Badger MR, Price GD (1992) The $\mathrm{CO}_{2}$ concentrating mechanism in cyanobacteria and green algae. Physiol Plant 84: $606-615$

Badger MR, Price GD (1994) The role of carbonic anhydrase in photosynthesis. Annu Rev Plant Physiol Plant Mol Biol 45:369-392

Bates NR, Michaels AF, Knap AH (1996) Seasonal and interannual variability of oceanic carbon dioxide species at the US JGOFS Bermuda Atlantic Time-series Study (BATS) site. Deep-Sea Res 43:347-383

Brewer PS, Goldman JC (1976) Alkalinity changes generated by phytoplankton growth. Limnol Oceanogr 21:108-117

Bruland KW (1989) Complexation of zinc by natural organic ligands in the central North Pacific. Limnol Oceanogr 34: $269-285$

Burns BD, Beardall J (1987) Utilization of inorganic carbon by marine microalgae. J Exp Mar Biol Ecol 107:75-86

Chavez FP, Buck KR, Service SK, Newton J, Barber RT (1996) Phytoplankton variability in the central and eastern tropical Pacific. Deep-Sea Res 43:835-870

Chen CY, Durbin EG (1994) Effects of pH on the growth and carbon uptake of marine phytoplankton. Mar Ecol Prog Ser 109:83-94

Chisholm SW (1992) Phytoplankton size. In: Falkowski PG, Woodhead AD (eds) Primary productivity and biogeochemical cycles in the sea. Plenum Press, New York, p 213-237

Clayton TD, Byrne RH, Breland JA, Feely RA, Millero FJ, Campbell DM. Murphy PP, Lamb MF (1995) The role of $\mathrm{pH}$ measurements in modern oceanic $\mathrm{CO}_{2}$-system characterizations: precision and thermodynamic consistency. Deep-Sea Res II 42:411-429

Cloern JE (1996) Phytoplankton bloom dynamics in coastal ecosystems: a review with some general lessons from sustained investigations of San Francisco Bay, California. Rev Geophys 34:127-168

Codspoti LA, Friederich GE, Hood DW (1986) variability in the inorganic carbon system over the southeastern Bering Sea shelf during spring 1980 and spring-summer 1981. Cont Shelf Res 5:133-160

Cooper DJ, Watson AJ, Ling RD (1998) Variation of $P_{\mathrm{CO}_{2}}$ along a North Atlantic shipping route (U.K. to the Caribbean): a year of automated observations. Mar Chem 60:147-164

Crawford DW, Harrison PJ (1997) Direct measurement of $\mathrm{pCO}_{2}$ in cultures of marine phytoplankton: how good is the estimate from $\mathrm{pH}_{\mathrm{NBS}}$ and single point titration of alkalinity. Mar Ecol Prog Ser 158:61-74

DOE (1994) Handbook of methods for the analysis of the various parameters of the carbon dioxide system in sea water version 2. Dickson A.G, Goyet C (eds). ORNL/CDIAC-74 U.S. Department of Energy

Gargett AE (1989) Ocean turbulence. Annu Rev Fluid Mech $21: 419-451$

Gavis J, Ferguson JF (1975) Kinetics of carbon dioxide uptake by phytoplankton at high $\mathrm{pH}$. Limnol Oceanogr 20 : $211-221$

Goldman JC (1984) Conceptual role for microaggregates in pelagic waters. Bull Mar Sci 35:462-476

Goldman JC (1988) Spatial and temporal discontinuities of biological processes in pelagic surface waters. In: Rothchild BJ (ed) Towards a theory on biologıcal and physical processes in the world ocean. Kluwer Academic, Dordrecht, p 273-296

Goldman JC (1993) Potential role of large oceanic diatoms in primary production. Deep-Sra Res 40:159-168 
Goldman JC, Glibert PM (1982) Comparative rapid ammonium uptake by four marine phytoplankton species. Limnol Oceanogr 27:814-827

Goldman JC, Hansell DA, Dennett MR (1992) Chemical characterization of three large oceanic diatoms: potential impact on water column chemistry. Mar Ecol Prog Ser 88: $257-270$

Hein M, Sand-Jensen $\mathrm{K}$ (1997) $\mathrm{CO}_{2}$ increases oceanic primary production. Nature 388:526-527

Hudson RJ, Morel FMM (1993) Trace metal transport by marine microorganisms: implications of metal coordination kinetics. Deep-Sea Res 40:129-150

Jordan DB, Ogren WL (1981) Species variation in the specificity of ribulose biphosphate carboxylase/oxygenase. Nature 291:513-515

Karp-Boss L, Boss E, Jumars PA (1996) Nutrient fluxes to planktonic osmotrophs in the presence of fluid motion. Annu Rev Oceanogr Mar Biol 34:71-107

Kiørboe T (1993) Turbulence, phytoplankton cell size, and the structure of pelagic food webs. Adv Mar Biol 29:1-72

Koch (1971) The adaptive responses of Escherichia coli to a feast or famine existence. Adv Microb Ecol 6:147-217

Korb RE, Saville PJ, Johnson AM, Raven JA (1997) Sources of inorganic carbon for photosynthesis by three species of marine diatom. J Phytol 33:433-440

Landrum LL, Gammon RH, Feely RA, Murphy PP, Kelly KC, Cosca E, Weiss RJ (1996) North Pacific Ocean $\mathrm{CO}_{2}$ disequilibrium for spring through summer, 1985-1989. J Geophys Res 101:28539-28555

Lazier JRN, Mann KH (1989) Turbulence and the diffusive layers around small organisms. Deep-Sea Res 36 $1721-1733$

Lee JG, Morel FMM (1995) Replacement of zinc by cadmium in marine phytoplankton. Mar Ecol Prog Ser 127:305-309

Lucas WJ, Berry JA (eds) (1985) Inorganic carbon uptake by aquatic photosynthetic organisms. Waverly Press, Baltimore

Mehrbach C, Culberson CH, Hawley JE, Pytkowicz RM (1973) Measurement of the apparent dissociation constants of carbonic acid in seawater at atmospheric pressure. Limnol Oceanogr 18:897-907

Michaels AF, Silver MW (1988) Primary production, sinking fluxes and the microbial food loop. Deep-Sea Res 35: $473-490$

Millero FJ (1995) Thermodynamics of the carbon dioxide system in the oceans. Geochim Cosmochim Acta 59:661-677

Millero FJ (1996) Chemical oceanography, 2nd edn. CRC Press, Boca Raton

Moloney CL, Field JG, Lucas MI (1991) The size-based dynamics of plankton food webs: II. Simulation of three contrasting southern Benguela food webs. J Plankton Res 13:1039-1092

Editorial responsibility: Otto Kinne (Editor), Oldendorf/Luhe, Germany
Morel FMM, Rienfelder JR, Roberts SB, Chamberlain CP, Lee JG, Yee D (1994) Zinc and carbon co-limitation of marine phytoplankton. Nature 369:740-742

Munoz J, Merrett MJ (1989) Inorganic-carbon transport in some marine eukaryotic microalgae. Planta 178:450-455

Nimer NA, Iglesias-Rodriquez D, Merrett MJ (1997) Bicarbonate utilization by marine phytoplankton species. J Phycol 33:625-631

Pahlow M, Riebesell U, Wolf-Gladrow DA (1997) Impact of cell shape and chain formation on nutrient acquisition by marine diatoms. Limnol Oceanogr 42:1660-1672

Pasciak WJ, Gavis J (1975) Transport limited nutrient uptake rates in Ditylum brightwellii. Limnol Oceanogr 20:604-617

Price NM, Morel FMM (1990) Cadmium and cobalt substitution for zinc in a zinc-deficient marine diatom. Nature 344 : $658-660$

Raven JA, Johnson AM (1991) Mechanisms of inorganic-carbon acquisition in marine phytoplankton and their implications for the use of other resources. Limnol Oceanogr 36 : $1701-1714$

Read BA, Tabita FR (1994) High substrate specificity factor ribulose bisphosphate carboxylase/oxygenase from eukaryotic marine algae and properties of recombinant cyanobacterial Rubsico containing 'algal' residue modifications. Arch Biochem Biophys 312:210-218

Riebesell U, Wolf-Gladrow DA, Smetacek AV (1993) Carbon. dioxide limitation of marine phytoplankton growth rates. Nature 361:249-251

Robertson JE, Robinson C, Turner DR, Holligan P, Watson AJ, Boyd P, Fernandez E, Finch $M$ (1994) The impact of a coccolithophore bloom on oceanic carbon uptake in the northeast Atlantic during summer 1991. Deep-Sea Res 41: $297-314$

Ryther JH (1969) Photosynthesis and fish production in the sea. Science 166:72-76

Schöne HK, Schöne A (1982) MET 44: a weakly enriched seawater medium for ecological studies on marine plankton algae, and some examples of its application. Bot Mar 25: $117-122$

Stuum W, Morgan JJ (1981) Aquatic chemistry, 2nd edn. John Wiley \& Sons, New York

Sunda WG, Huntsman SA (1995) Cobalt and zinc interreplacement in marine plankton: biological and geochemical implications. Limnol Oceanogr 40:1404-1417

Tortell PD, Reinfelder JR, Morel FMM (1997) Active uptake of bicarbonate by diatoms. Nature 390:243-244

Wanninkhof R, Feely RA (1998) $f \mathrm{CO}_{2}$ dynamics in the Atlantic, South Pacific, and South Indian oceans. Mar Chem 60:15-31

Wolf-Gladrow D, Riebesell U (1997) Diffusion and reactions in the vicinity of plankton: a refined model for inorganic carbon transport. Mar Chem 59:17-34

Submitted: August 17, 1998; Accepted: December 7, 1998 Proofs received from author(s): April 6, 1999 